\title{
EPISTEMOLOGICAL VIEWS OF ISLAMIC EDUCATION PHILOSOPHY AS A ISLAMIC EDUCATION BASIS
}

\author{
Muh. Haris Zubaidillah \\ Dosen, STIQ Amuntai, Kalimantan Selatan, Indonesia \\ Email: hariszub@gmail.com
}

\begin{abstract}
This paper briefly discusses one of the foundations of Islamic education, the epistemological view of Islamic education philosophy. Islamic education as an effort in shaping humanity and civilization must have a firm foundation upon which all activities are connected or propped up. In terms of epistemological, the foundation of Islamic education is the epistemological philosophy of Islamic education sourced from the Qur'an and As-Sunnah as the primary source, as well as the Ijtihad and the intellect that became the branch (furu') of the development of these two primary sources. So that Islamic education really serves as a medium of influencing others toward a better direction in order to live better in accordance with the teachings of Islam and obey all that is ordered and away from all the banned with the awareness of human beings are firmly planted with the scientific aspect so that the result is not just obedient blindness but scholarly servitude, all done within the scope of God's rule. In the end the foundation of education itself is none other than the source of the teachings of Islam that is Al Quran and AsSunnah.
\end{abstract}

Keywords: Epistemological, Philosophy, Education and Islam

\section{A. Introduction}

The cornerstone is something that rests all the basics in a building, while the foundation is the fundamental that upholds a building, so that it becomes strong and solid in the development of Islamic education. In an attempt, deliberate activity and action to achieve a goal must have a proper foundation as a good and strong footing ground. Therefore, Islamic education as an effort in shaping human beings and civilization must have a strong foundation on which all activities are connected or propped up. Both as a source

Jurnal Ilmiah Al QALAM, Vol. 12, No. 1, Januari-Juni 2018 
Muh. Haris Zubaidillah: Epistemological Views Of Islamic Education Philosophy As A Islamic Education Basis

and basis that guides the implementation and development. ${ }^{1}$ Among the cornerstones of Islamic education is the epistemological view of the philosophy of Islamic education in order to provide guidance on the source and foundation of truth to realize Islamic education in accordance with the values of Islamic teachings.

Departure from the description, then in this paper the author will explain about the epistemological view of Islamic education philosophy as the foundation of Islamic education.

\section{B. Epistemological View of Islamic Education Philosophy}

In the epistemological view of the philosophy of Islamic education, the source and basis of truth are all things derived from the Qur'an and Sunnah of Prophet Muhammad SAW which can be developed with ijtihad, mashlahah almursalah, istihsan, qiyas and so on. ${ }^{2}$

According to Marimba, the foundations and fundamentals of a building are part of the building which is the source of strength and firmness that keeps the building upright. Thus, the function of the epistemological education of Islam is in addition to the establishment of a building in the world of Islamic education, also so that the building will not be swayed by various "issues" that affect it and even he will be stronger and stronger in the face.

The epistemological view of Islamic education philosophy is a view of Islamic education based on the Qur'an and al-Hadith as the primary source, and the opinions of experts, especially the companions of the prophet SAW as a secondary source. Thus it can be said briefly that the epistemological philosophy of Islamic education is a view of Islamic education based on Islamic teachings or educational philosophy imbued with Islamic teachings. The fundamentals of Islamic education are principally laid on the foundations of Islamic teachings and all of its cultural tools. The foundations of the

\footnotetext{
${ }^{1}$ Zakiah Darajat, Ilmu Pendidikan Islam, (Jakarta: Bumi Aksara, 1996), n. 19.

${ }^{2}$ Zakiah Darajat, Ilmu Pendidikan Islam..., n. 21-22
}

Jurnal Ilmiah Al QALAM, Vol. 12, No. 1, Januari-Juni 2018 
Muh. Haris Zubaidillah: Epistemological Views Of Islamic Education Philosophy As A Islamic Education Basis

establishment and development of Islamic education first and foremost of course the Qur'an and Sunnah. The Qur'an, for example, provides the principle of reverence for reason, scientific guidance, not against human nature and maintains social needs which are very important for education. ${ }^{3}$

Islamic education according to Adi Sasono is derived from the teachings of the Divine, then of course must be sourced from the truth and greatness of the Divine. For us the source of divine truth has been introduced to man through the prophets in the form of scripture. Of the four scriptures that have been revealed as the guidance of mankind, then since the presence of the Prophet Muhammad. on the face of this earth one that must be upheld and strengthened that is the Qur'an. In addition, the decrees of Rasul SAW are also a major source of Islamic education (1998: 90). ${ }^{4}$

Basically the shari'ah building and the Islamic morality have two main sources namely al-Qur'an al-Karim and the sunnah of the Prophet SAW. The Qur'an is the book of Allah revealed to the prophet Muhammad bin Abdillah, with a clear and eloquent Arabic language chronologically descended within a span of approximately 23 years, which has values of worship. As well as the second Islamic source is al-Sunnah as the foundation of thought and shari'ah consisting of everything derived from Rasul saw.

Thus, the source and basis of Islamic education can be explained as follows:

\section{The Quran}

The Quran as kalamullah covers all aspects of human life issues in interacting with his creators, human beings and the universe which is the fundamental problem in every human life. The Qur'an has a very broad fundamental idea in the various areas of human life which all can and should serve as a basic foundation in the development of Islamic Education. The

${ }^{3}$ Ahmad D. Marimba, Pengantar Filsafat Pendidikan Islam, (Bandung: AlMa'arif, 1980), n. 41.

${ }^{4}$ Adi Sasono, Solusi Islam Atas Problematika Umat Ekonomi, Pendidikan dan Dakwah,(Jakarta: Gema Insani Press, 1998), n. 90.

Jurnal Ilmiah Al QALAM, Vol. 12, No. 1, Januari-Juni 2018 
Muh. Haris Zubaidillah: Epistemological Views Of Islamic Education Philosophy As A Islamic Education Basis

position of the Qur'an in the framework of Islamic Education is not only as a basis even to be a valuable resource for continually explored, understood and taken in its intentions to be actualized in life and human life.

The position of the Qur'an as the source and epistemological foundation of Islamic education philosophy is very important, because in Al qur'an there is a teaching that contains principles related to the activity or business of that education. Al qur'an is a clue that when studied will help find value values that can be guided by various life problems. When practiced and practiced it will make the mind, taste, and will lead to the reality of the faith required to stabilize and uphold the personal life and society.

In essence the Qur'an is a great treasure for human culture, especially in the spiritual field. Al Quran is also a book of social education, moral (moral) and spiritual spirituality.

Al Quran is also the main source of Islamic education. As Allah SWT says in the QS. An Nahl: 89.

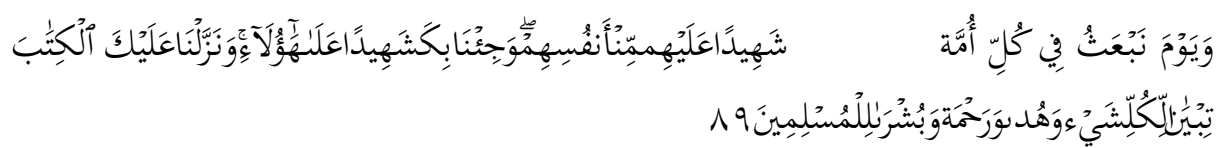

"And We have sent down to you the Book to explain all things, and guidance and mercy and good tidings for those who surrender." (QS. An-Nahl: 89)

The Qur'an is also the guiding principle of the most straightforward, as the word of Allah in the QS. Al Isra: 9.

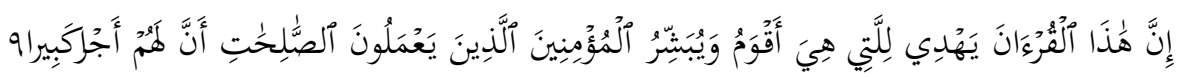

"Verily, this Qur'an gives guidance to a straight path and gives good news to the Mu'min who do good deeds that they have a great reward." (QS. AlIsra: 9) 
Muh. Haris Zubaidillah: Epistemological Views Of Islamic Education Philosophy As A Islamic Education Basis

As the Quran contains the instructions for humanity in all its aspects that build mankind to be a devout Muslim. Because of the main foundation and holistic Islamic teachings of the Quran, then in developing the Islamic education wing should be able to translate the Al Quran intelligently into human language. In order for the Qur'an to be more contextual with the circumstances of the times because the Qur'an contains complete teachings in various aspects. The Qur'an is a source of teachings and Islamic philosophy timeless. That in other words the teachings contained in it have been ensured to contain universal teachings and need to be translated substantially. So Islamic education should be when experiencing the setbacks and fading of synergies in the practical square should be restored to the basis of Islamic education ie the fundamentals of Islam as outlined in the Quran. The Quran contains and brings values that cultivate humanity. Al Quran is able to create a believer and always on Allah SWT. And believe the last day. Al Qu'ran started his education from concrete things like wind, rain, and plant growth. And abstract things like existence, power and greatness and various properties of Allah SWT. This is a subject of study in Islamic philosophy.

\section{The Sunnah}

The Sunnah means the whole attitudes, words and actions of Rasulullah SAW in applying the teachings of Islam and developing the lives of human beings that truly bring to the praise of all the worlds, including humans in actualizing themselves and their lives in full and responsible for salvation in their lives. The position of al-Sunnah in life and Islamic thought is very important, as in addition to reinforcing and clarifying various issues in the Qur'an, it also provides a more concrete basis for the application of various activities that must be developed within the framework of life and human life.

In the world of sunah education there are two great benefits, namely:

(1) Explaining the Islamic education system contained in the Qur'an or explaining things that are not contained therein; (2) Conclude the method of

Jurnal Ilmiah Al QALAM, Vol. 12, No. 1, Januari-Juni 2018 
Muh. Haris Zubaidillah: Epistemological Views Of Islamic Education Philosophy As A Islamic Education Basis

education from the life of the Prophet SAW with his companions and cultivation of faith into his soul.

The Prophet's Sunnah in educating his people has two methods: First, Positive, in the sense of making a person glorious with his knowledge and morals. And secondly: The nature of care, in the sense of avoiding a person of all ugliness and safeguarding unity from disunity. ${ }^{5}$

Hadith in his position became the source of philosophy and at the same time became the second source of Islamic education after the Quran.

Hadith or sunnah being the source of Islamic education herein is all references or references containing science and values that will be internalized in Islamic education. The study of Islamic education can not be separated from the foundation associated with the first source of Islamic teachings, namely the Qur'an, For every people who embrace Islam as their religion is awarded by God a comprehensive Qur'anic Qur'an explaining the fundamental teachings which covers all aspects of human life. And the hadith explains in detail the contents of the Quran that is still common.

Hadith is more likely to be applicable because the elements in the hadith are also part of the revelation as well as the form of responsibility for the issues arising because the hadith is the interpretation and summary of the great figure in Islam that is the Messenger of Allah. So the concept of Islamic education highlights the morality and education.

Along with the advancement of times and cultural differences, the demands and concerns of the people become complex and evolving. So here is the role of the Qur'an and the hadith as a source of reference to solve various problems because the Qur'an and hadith is a source of time limitless law.

It demands intelligence and understanding to better understand the messages and laws of both sources of Islamic teachings. So Islamic education still refers to both sources.

\footnotetext{
${ }^{5}$ Abdurrahman An-Nahlawi, Pendidikan Islam di Rumah, Sekolah, Masyarakat.(Jakarta: gema insane press, 1995), n. 47.
}

Jurnal Ilmiah Al QALAM, Vol. 12, No. 1, Januari-Juni 2018 
Muh. Haris Zubaidillah: Epistemological Views Of Islamic Education Philosophy As A Islamic Education Basis

\section{Ijtihad}

The Ijtihad referred here is the translation and understanding of both sources namely Alquran and Hadith. Ijtihad is used because of the many problems that today's development in education. So that ijtihad becomes the source of Islamic education philosophy after the Quran and Hadith in the education. Because of the need to think of new thinking related to the advancement of science and technology, so that in need of Islamic breakthrough as a support in the development of Islamic education systematically.

The development of a systematic system of education is a key hope for improving the current Islamic education system. Thus, with the development of an educational system that embraces good new things, it is imperative but with a note in accordance with the basic concepts of the foundation of Islamic education namely the Qur'an and the Hadith because by opening to something good in accordance with dialectics of education. Because education not only teaches a certain amount of knowledge, but rather teaches how that knowledge is organized and found.

Ahmad tafsir in Supriayadi, adds reason as the foundation and source of Islamic education philosophy. Allah SWT Said:

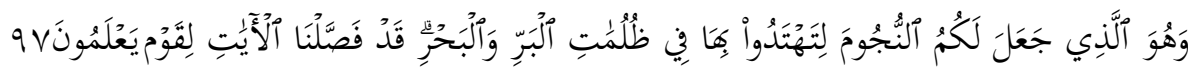

"And he is the one who made the stars for you, so that you might make him a guide in the darkness of the land and in the sea. Indeed, We have made clear signs to those who know. "(QS. Al An'am: 97)

The above description of the Quran explains that in the teachings of Islam, the intellect occupies a very important position after the Quran and Hadith. Because reason is widely used not only in the development of science and culture but also in the development of the teachings of Islamic religious teachings itself.

Jurnal Ilmiah Al QALAM, Vol. 12, No. 1, Januari-Juni 2018 
Muh. Haris Zubaidillah: Epistemological Views Of Islamic Education Philosophy As A Islamic Education Basis

However, in Islam, the use of reason is not given absolute freedom so that the Islamic thinker can break the lines that have been set by the Qur'an and Hadith. It is necessary to emphasize here that the good use of the Qur'an is to be instructed in order to encourage people to research the surrounding environment and to develop science. The proper use of reason in order to understand the nature of something is truly the philosophy world.

In the world of philosophy, reason is used as a form of deep thought in science.

From the description above, it can be understood that the epistemological view of the Islamic education philosophy is a view of the source developed and developed in Islamic education both philosophically, as well as theoretical and empirical in the world of Islamic education is the Quran and As-Sunnah. It can thus be argued that the thought about the foundation which is the basic source of Islamic education is the Qur'an and al-Sunnah which became the primary source and then Islamic thought, ijtihad and intellect that became the branch of the development of these two primary sources. ${ }^{6}$

The epistemological view of the Islamic education philosophy mentioned above, in accordance with the Prophet's Sura in a hadith narrated by Ahmad, Abu Dawud and Tirmidzi.

$$
\text { وأما بعث النبي معاذ بن جبل إلى اليمن قاضيا, قال له: (كيف تقضي إذا عرض لك قضاء ؟ج) قال: }
$$

\footnotetext{
${ }^{6}$ Dedi Supriyadi, Filsafat Islam Konsep, Filosuf, dan Ajarannya, (Bandung: Pustaka Setia, 2009), n. 43.
}

Jurnal Ilmiah Al QALAM, Vol. 12, No. 1, Januari-Juni 2018 
Muh. Haris Zubaidillah: Epistemological Views Of Islamic Education Philosophy As A Islamic Education Basis

"When the Prophet sent his Companion Muadz bin Jabal to Yemen as judge the Prophet asked: How do you judge a legal matter? Muadz replied: I will decide with the Quran. The Prophet asked: If you do not find it in the Quran? Muadz replied: With the sunnah of the Messenger of Allah. The Prophet asked: If you did not find it? Muadz replied: I will be in agreement with my opinion and will not look to other. Muadz said: Then the Prophet struck my chest and said: Praise be to Allah who has helped his messenger Rasulullah because the Prophet liked the attitude of Muadz. "(Hadith reported by Ahmad, Abu Dawud and Tirmidzi)

\section{Epistemological View of Philosophy of Islamic Education as the basis of Islamic Education}

It is a must, that every intentional effort, action and activity to achieve the goal must have the basis of a strong foundation, as well as Islamic education, in order to establish a person of good personality must have a good and precise systemic basis according to Islamic principles. In a good Islamic education activity in the preparation of theoretical concepts and in the implementation of its operational must have a solid basis based on the teachings of Islam. It is intended that the one in Islamic education has a firm conviction that practice does not lose its direction and is easy to grow.

The epistemological view of the Islamic education philosophy as the foundation of Islamic education serves as a medium influencing others to a better direction in order to live better in accordance with Islamic teachings and to adhere to all that is commanded and to keep away from all that is prohibited by human consciousness that is deeply embedded in science the result is not merely obedient to blind but conscientious servitude. Everything is done in the scope of God's law. Ultimately the basis of the education itself is none other than the source of the teachings of Islam ie the Quran and As-Sunnah.

Jurnal Ilmiah Al QALAM, Vol. 12, No. 1, Januari-Juni 2018 
Muh. Haris Zubaidillah: Epistemological Views Of Islamic Education Philosophy As A Islamic Education Basis

\section{Conclusion}

Islamic education as an effort in shaping humanity and civilization must have a firm foundation upon which all activities are connected or propped up. Both as a source and foundation that guides its implementation and development. Among the cornerstones of Islamic education is the epistemological view of the philosophy of Islamic education in order to provide guidance on the source and foundation of truth to realize Islamic education in accordance with the values of Islamic teachings.

The epistemological view of the philosophy of Islamic education is a view of the source built and developed in Islamic education both philosophically, and theoretically and empirically in the world of Islamic education is the Qur'an and As-Sunnah. Thus it can be stated that the idea of the basis upon which Islamic education is the basis of the Qur'an and al-Sunnah is the primary source of Islamic thought, ijtihad and the intellect of the two primary sources.

Therefore, the epistemological view of Islamic education philosophy as the foundation of Islamic education serves as a medium for influencing others toward a better direction in order to live better in accordance with the teachings of Islam and obey all that is commanded and away from all that is prohibited with the awareness of the man who is firmly planted with the scientific aspect so that the result is not merely obedient blind but scholarship based on scholarship. All that is done within the scope of God's rules. In the end the foundation of education itself is none other than the source of the teachings of Islam that is Al-Quran and As-Sunnah.

Jurnal Ilmiah Al QALAM, Vol. 12, No. 1, Januari-Juni 2018 
Muh. Haris Zubaidillah: Epistemological Views Of Islamic Education Philosophy As A Islamic Education Basis

\section{References}

An-Nahlawi, Abdurrahman, Pendidikan Islam di Rumah, Sekolah, Masyarakat.Jakarta: Gema Insani Press, 1995.

Prinsip-Prinsip dan Metode Pendidikan Islam. Bandung:

Diponegoro, 1992.

Azra, Azyumadi, Esai-Esai Intelektual Muslim dan Pendidikan Islam, Jakarta:

Logos Wacana Ilmu, 1999.

-----------------------, Pendidikan Islam Tradisi dan Modernisasi Menuju Millenium Baru, Jakarta: Logos Wacana Ilmu, 1999.

Darajad, Zakiah, dkk., Ilmu Pendidikan Islam, Jakarta: Bumi Aksara, 1996.

Marimba, Ahmad D., Pengantar Filsafat Pendidikan Islam, Bandung: alMa'arif, 1980.

Nata, Abuddin, Filsafat Pendidikan Islam, Jakarta: Logos Wacana Ilmu, 1997. Tafsir Ayat-Ayat Pendidikan Tafsir al-Ayat al-Tarbawiy. Jakarta: Raja Grafindo, 2010.

Sasono, Adi, Solusi Islam Atas Problematika UmatEkonomi, Pendidikan dan Dakwah,Jakarta: Gema Insani Press, 1998.

Supriyadi, Dedi, Filsafat Islam Konsep, Filsuf, dan Ajarannya, Bandung: Pustaka Setia. 2009.

Uweis, Abdul Halim, Koreksi Terhadap Umat Islam Suatu Telaah dan Alternatif Jawabannya, terj. Abu Hurairah., Jakarta: Darul Ulum Press, 1989.

Jurnal Ilmiah Al QALAM, Vol. 12, No. 1, Januari-Juni 2018 
Muh. Haris Zubaidillah: Epistemological Views Of Islamic Education Philosophy As A Islamic Education Basis

Jurnal Ilmiah Al QALAM, Vol. 12, No. 1, Januari-Juni 2018 